\title{
Information Technology as the Main Competence in the Design of the Strategic Planning of Logistics Platforms
}

\author{
Leonardo Varella', Mirian Buss Gonçalves²
}

\begin{abstract}
The creation of logistical support structures aims to help improve the performance of logistics along supply chains, a context where the Logistics Platforms have been gaining increasing prominence. A frequent difficulty in these ventures is to align strategic planning with the flow of cargo and the ability of the adjacent port areas. Aiming to contribute to the understanding of the importance of Information Technology in a Logistics Platform, this article systematize some of the operational core competencies of Logistics Platforms, inter-relating them with the strategic planning of these projects and showing their convergence to a solid information management structure. This study indicates the importance of this essential skill in the operation of a logistics enterprise and the preparation of its strategic plan, shown to be fundamental in the design of its operations, the adequacy of the enterprise to the region and to supply chains integrated into this environment.
\end{abstract}

Keywords: logistical structures, it, strategic planning, logistic platforms, cargo, supply chains.

1,2UFSC - Universidade Federal de Santa Catarina- Programa de Pós-Graduação em Engenharia de Produção. E-mail: leonardo.varella@gmail.com 


\section{Introduction}

Logistics Platforms are organizational structures that promote coordination and connection points of the supply chain (Varella et al. 20II). Aim to ensure fluidity between transportation connections and coordination of transportation modals (Colin, 1996). According to Weisbrod (2002), are clusters with intermodal quality facilities and logistics distribution within a secure perimeter where a range of services is offered to partners tenants.

Logistics Platforms are inserted in a context that seeks a better agility and logistics efficiency of their processes. This demand for better coordination and organization of spaces and logistics activities has motivated the creation of structures of logistical support. For that, Bowersox et al. (2003) advocate the generation of partnerships involving job sharing, information, resources, risks and objectives. Sahay (2003) ensures that the vision of the collaborative process, alignment with suppliers, producers, distributors and customers generates benefits to the chain and to each agent, considering not only the individual results, but the whole chain.

For the proper functioning of a Logistics Platform is important to have a strategic plan that addresses the needs of the supply chains. It seeks, through this study, to analyze the importance of the development of these essential competencies of operation of a Logistics Platform in the strategic framework, in particular relating to Information Technology as a support to other skills, interrelated them with the strategic vision and goals sought for this type of logistics project. For this study, a literature and field search was conducted, with exploratory and descriptive nature. A qualitative approach was adopted, developed through a case study involving interviews with managers of a logistical undertaking.

\section{Logistics Platforms}

The increasing operational globalization has led organizations to seek new solutions to remain competitive in this new context. For a company to be inserted in this market, a new global scenario, Lima et al. (1998) argue that it is necessary to have an advanced infrastructure formed by the combination of three factors: a basic transports network of quality that provides various transportation alternatives, a telecommunications network that ensures the integrity and transmission of data and information in real time, and information technologies, indispensable for the understanding and treatment of data. It was also noted that to develop an advanced and modern infrastructure is necessary to have

\begin{tabular}{|c|c|c|}
\hline Authors & Essential Definition & Theoretical Foundations \\
\hline BASTOS et al., 2010 & $\begin{array}{l}\text { Point where there is a concentration of } \\
\text { activities related to logistics, or activities between } \\
\text { one or more modals. }\end{array}$ & $\begin{array}{l}\text { Logistics location } \\
\text { Multimodality }\end{array}$ \\
\hline WEISBROD, 2002 & $\begin{array}{l}\text { Cluster with quality intermodal facilities } \\
\text { and logistics distribution within a secure perimeter } \\
\text { where a range of services is offered to partners } \\
\text { tenants. }\end{array}$ & $\begin{array}{l}\text { Logistics location } \\
\text { Multimodality }\end{array}$ \\
\hline $\begin{array}{l}\text { ABRAHAMSSON et } \\
\text { al., } 2003\end{array}$ & $\begin{array}{l}\text { Centralizations that controls and projects } \\
\text { the focus of organizations, being flexible to change } \\
\text { and react quickly to the market. }\end{array}$ & $\begin{array}{l}\text { Logistics location } \\
\text { Flexibility }\end{array}$ \\
\hline DUBKE et al., 2004 & $\begin{array}{l}\text { Logistics locations that meet the lowest } \\
\text { cost, best service levels for certain goods. }\end{array}$ & $\begin{array}{l}\text { Logistics location } \\
\text { Cost minimization }\end{array}$ \\
\hline DUARTE, 1999 & $\begin{array}{l}\text { Location of maximum efficiency through } \\
\text { the optimization of transportation services, ware- } \\
\text { housing, distribution, and other activities.. }\end{array}$ & $\begin{array}{l}\text { Logistics location } \\
\text { Adding value } \\
\text { Multimodality }\end{array}$ \\
\hline $\begin{array}{l}\text { EUROPLATFORMS, } \\
2004\end{array}$ & $\begin{array}{l}\text { Defined location where all logistics activi- } \\
\text { ties are carried out, transportation and distribution } \\
\text { of goods that should, preferably, be served by a } \\
\text { range of transport modals. }\end{array}$ & $\begin{array}{l}\text { Logistics location } \\
\text { Multimodality }\end{array}$ \\
\hline
\end{tabular}

Chart I Conceptual characterization of logistics plataforms

ISSN: 07I 8-2724. (http://www.jotmi.org)

Journal of Technology Management \& Innovation (c) Universidad Alberto Hurtado, Facultad de Economía y Negocios. 
available an adequate infrastructure and an institutional environment, fiscal and regulatory able to enhance the coordination and synchronization between the various agents and segments of the value chain.

A logistics platform is a logistics environment in which concentrate logistics activities and support services, aiming to add value to the product involved in the process, being common the occurrence of transfer between modals. It's an undertaking propped within the ambit of strategic conception in the following triad: infrastructure and services, location, investment (Varella et al., 20I I). It's necessary to have an alignment between these foundations so that it meets the needs of concerned parties in the investment and respects such restrictions relating to it and environment limitations. The coordination of administrative and operational processes, with the common goal of planning global solutions and sustainable for logistics systems transportation, of goods and people is the main challenge for the formulation of a strategic planning for a Logistics Platform. Chart I presents a summary of the characterization of Logistics Platforms according to various authors:

\section{Strategic Planning}

Developing and performing business strategies to gain space in competitive markets is a highly complex task, since the actual formulating a strategy is already a task that involves multiple agents, factors and components, and to gain control over the same requires attention and a certain holistic understanding of the market. Considered these difficulties, strategic planning is presented as a valuable management tool to aid the design and scope of these strategies and goals, handled by the high organizational management and implemented at all levels of the hierarchical corporative pyramid. This allows guiding the main administrative and managerial actions of the enterprise, seeking to achieve goals that prove strategic for the organization at that time. It is a tool for constant application, since the market is always renewing itself, is not an unchanging entity, as an organization can never be. Aim to reduce the possibility of making wrong decisions in an extremely competitive market, leaving no room for mistakes.

For Kotler (1992), "Strategic planning is defined as the managerial process of developing and maintaining a reasonable adequacy between the objectives and resources of the company and the changes and market opportunities." His goal is to guide and re-guide the business and products of the company so that generates profits and satisfactory growth. Barbosa and Brondani (2004) say that strategic planning is the strategy itself, being, for each type of business the company has to create a strategy to achieve long-term goals, because there isn't only one satisfactory strategy for all competitors.
This way, the organization must choose what is best for itself (and, if possible, for the chains involved), taking into account their market position, objectives, opportunities and resources available.

It's consensus that currently the great organizations go through market turmoil and twists more frequently and with greater impact on organizational strategies, the organizational environment can be described today as a random environment, with minimal placidity and tranquility, and it is in this environment that the actions in favor of the strategy help balance the current situation with the future vision of the organization. There for, the strategy unfolds in tactics, quick attacks (blitzkrieg) situations in order to implement solutions and realign the objectives to be achieved with measures taken at the present time, turbulent or not, placid or not.

In this scenario, this paper proposes to examine the importance of Information Technology (IT) as essential skills in strategic operational planning of Logistics Platform, using this as an auxiliary tool for managing an organization set in a competitive and demanding market that is the service for supply chains and cargo transportation logistics, especially when exploited and enhanced by two other skills already worked by Varella et al. (2012): The Collaboratively and Integration in the Supply Chain.

\section{Collaboratively, Integration \& Information Technol- ogy and Communication in the Supply Chain}

To continue serving and satisfying customers in the logistics market and logistics services and to be able to provide solutions consistent with the reflexes imposed by globalization and the new order mercantile world, new ideas and strategies have been developed to leverage the effectiveness and participation of key links in the chain supply of interest in the organizations that permeate this market. Therefore, throughout the development of the current logistics concepts, the management of the supply chain has also become a key factor to improve the cost and quality of services, achieving greater prominence and relevance in the strategic planning of organizations. Stefansson (2005) says that there was an intensive discussion in recent years, about relationships in the logistics, especially in the supply chain management and the relations between the companies forming trade links, links that are completed in the same or adjacent chains. To this end, collaborative management occurs when, according Simatupang et al. (2002), there is the shared responsibility of two or more companies, sharing the planning, the administration, the execution and the results of the supply chain. Bowersox et al. (2003) advocate the generation of partnerships involving job sharing, information, resources, risks and objectives, while Sahay (2003) says that in a cooperative 
relationship, in view of the collaborative process, alignment with suppliers, producers, distributors and customers means benefits to the chain and to each agent considering not only the individual results, but the whole chain.

Based upon this premise, the work of Mehrjerdi (2009) is correlated with the research in question. The author states that collaboration for sharing information (ex. inventory, sales, demand forecasting, status of orders, and production scheduling) is important to facilitate the integration and automation, providing competitive advantages to the chain. To Albertini (2004) IT is all that we can store, process, communicate and provide in information that is useful in internal operations (intra-operability) and external relations (interoperability). And the third propelling aspect is the Confidence, because according to Vivaldini et al. (2010), in exchanging information, companies would feel insecure to share all these information because their businesses would be exposed. However, Mehrjerdi (2009) states that "when the confidence level is high the performance of supply chains is enhanced, thus facilitating the spread of services, ideas, and information."

Organizations seeking to refine their supply chain have highlight an emphasis on developing closer relationships with its suppliers, distributors or consumers, looking to create longterm bonds and more friendly policies with its partners, based on the premise that the cooperatively, seeking greater integration of processes and systems between participating companies in the supply chain, results in greater efficiency holistic. (LEE;WHANG, 2004).

\section{The vital role of IT in supply chains}

Information Technologies (IT) are used by people in the processes of storage, restoration, transformation, dissemination and integration of data and information in an organization, improving the efficiency and effectiveness of the processes as a whole (CHEN Y.M.; LIANG M.W., 2000; O'BRIEN; MARAKAS, 2007 apud VIEIRA, 2012). Gunasekaran and Ngai (2003) justify that companies with better corporate performance are those that use most ostensibly the ICT tools, especially the most advanced on the market. IT applied to logistics enables a better control of the information flow of the chains involved, acting jointly, giving sustenance to logistics information systems (GUNASEKARAN; NGAI, 2003). Fleury et al. (2000) present the following definition: "The logistics information systems works as links that connect the logistics activities in an integrated process, combining hardware and software to measure, monitor and manage logistics operations. These operations both occur within a specific company, as well as along the entire supply chain." Using the information and leverage resources available to coordinate actions, prioritizing information flows, is one of the success factors for the integration of information technology with other skills in a Logistics Platform. (MONTEIRO; BEZERRA, 2003). Nevertheless, despite new technologies prove quite promising and assist in this integration, examples of successful transformation of the practices of supply chains for greater integration are still relatively few.

\section{Method}

\section{Subjects or Participants}

For this study, three Logistics Platforms (LP) located in state of Santa Catarina were analyzed. They have an area of influence that includes the states of Santa Catarina, Rio Grande do Sul, Paraná, Mato Grosso, Mato Grosso do Sul and São Paulo, and they are currently the main route to import/export goods through Santa Catarina's ports. In this study, we also considered the characterizing elements these environments (based on their current facilities, customer portfolio, services offered and strategic future planning) and a direct and unstructured interview with the managers of these enterprises, enabling a detailed survey of the characterizing structures of the enterprise, supply chains and economic context where it is embedded.

Strategic planning of a logistical undertaking was conceived through an analysis based mainly on the following items: location of the project, cargo handling and capillary modal of the region adjacent, clientele through value chains, operation and logistics services aggregated provided by the undertaking, as seen in through studies of Carvalho (20I0)

\section{CASE I}

This environment is located in Itajaí near a major highway that connects the coast to other distant Santa Catarina's cities, and this can be seen in the influx of goods the logistics platform currently operates (its main companies and goods), as it can be characterized in Chart 2:

\section{CASE 2}

This environment is, as in Case I, also located in the Itajai port area. It operates exclusively with frozen cargo in reefer containers, and is the most used logistics platform in region for exporting frozen cargo, offering the fastest cargo-handling for reefer containers and quickest route for exportation. It can be characterized in Chart 3:

\section{CASE 3}

This Logistics Platform is located in São Francisco do Sul, near Joinville, the largest city in Santa Catarina and the core of the heavy-industry supply chain in Santa Catarina (located in the north area of the State). Chart 4 presents its logistical undertaking as follows:

\section{Apparatus}


To contribute to the extern validity of the study, were selected consolidated companies operating in bonded warehouse terminals in the region of the northern coast of Santa Catarina, seeking within these experienced respondents with holistic environment knowledge, preferably in higher hierarchical level, seeking to obtain data for an analysis not only operational but also management of the enterprise. Were presented for these the research objectives and the relevance of the ventures for research topics, the study script and an explanation of how the organization could contribute to the study. The interviews with those responsible lasted about 3 hours, occurring in the examined logistics environment and recorded in document for later analysis, followed later by a wider visit to the site, presented the facilities, services offered, and corporative organization where more questions could be analyzed and recorded, along with an on-site visit of operations, contact with customers, scouting of strategic practices, technical support and provision of adequate documentation.

\begin{tabular}{|l|l|}
\hline Location & \multicolumn{2}{|c|}{ Itajaí } \\
\hline Size & Medium (about $100.000 \mathrm{~m}^{2}$ ). \\
\hline Management & Private. \\
\hline Transportation Modals & $\begin{array}{l}\text { Multimodal. Maritime (main) road (secondary), air transportation } \\
\text { (tertiary); }\end{array}$ \\
\hline Intermodality & $\begin{array}{l}\text { Yes, under implementation (air transportation and possible rail). Currently } \\
\text { operates only through the road, and the road connects to the harbor with } \\
\text { the waterway. }\end{array}$ \\
\hline Main Companies and Goods & $\begin{array}{l}\text { Pharmaceutical network and hospital equipment, car dealers and trans- } \\
\text { port of refrigerated cargo, loads of high value-added, manufactured } \\
\text { products. }\end{array}$ \\
\hline Services & $\begin{array}{l}\text { Customs, security, transportation, tracking and support services (dispatch, } \\
\text { internet, food). }\end{array}$ \\
\hline
\end{tabular}

Chart 2 Characterization of the Logistic Platform I:

\begin{tabular}{|l|l|}
\hline Location & Itajaí \\
\hline Size & Medium (about $\left.75.000 \mathrm{~m}^{2}\right)$. \\
\hline Management & Private. \\
\hline Transportation Modals & Multimodal. Maritime (main) road (secondary); \\
\hline Intermodality & Yes. \\
\hline Main Companies and Goods & Transport of reefer cargo (BRF, JBS-Friboi, Perdigão, Macedo). \\
\hline Services & Customs clearance, refrigeration. \\
\hline
\end{tabular}

Chart 3 Characterization of the Logistic Platform 2:

\begin{tabular}{|l|l|}
\hline Location & São Francisco do Sul (north of Santa Catarina) \\
\hline Size & Medium (about $\left.100.000 \mathrm{~m}^{2}\right)$. \\
\hline Management & Private. \\
\hline Transportation Modals & Multimodal. Maritime (main) road (secondary), air transportation (tertiary); \\
\hline Intermodality & Yes \\
\hline Main Companies and Goods & Steel, Pharma, Toys, Copper. \\
\hline Services & Customs, security, transportation, tracking and support services (dispatch, internet, food). \\
\hline
\end{tabular}

Chart 4 Characterization of the Logistic Platform 3:

ISSN: 07 I8-2724. (http://www.jotmi.org) 
The construction of the questionnaire was done through the conception, evaluation and revision of the research object, covering physical aspects, geographical and strategic of the development, seeking to analyze variables considered during strategic planning (IT Infrastructure integrator; Intermodality; Accessibility to the consumer; Accessibility to supply chains) services offered, supply chains that attend to, among other things. This case study will seek to detail the processes involved in the undertaking analyzed in its logistics network by identifying the chain agents, their relations of cooperation and partnership, synergy between them, process requirements, the processes involved in the undertaking development and the needs of managers at the beginning of their operations and currently, to be able, through the analysis of collected data, (in the form of an unstructured interview, empirical nature) to detect which skills are paramount for strategic planning of the enterprise and its intrinsic relationship with Information Technology, sustaining the premises of Mehjerdi work (2009) through previous studies of Feldens (2005) and the research in loco of authors here proposed.A similar work (although in a different context) was presented in 2008. (Bandeira and Maçada, 2008)

\section{Procedure}

This study is characterized as a field research exploratory and descriptive, with qualitative approach, developed through a multiple case study using the method of content analysis through interviews with the logistics manager of 3 environments. Initially a review of the literature relevant to the topics discussed, followed by the development of an explanatory case study (for construction and verification of theory) with the following steps (Miguel, 2010): (i) definition of conceptual-theoretical structure and plausible environments; (ii) direct observation, interview with the managers of such establishments and documentary analysis of primary data; (iii) analysis of results; (iv) conclusions and final report of the study. To do so, because it is investigative and directly related to consolidated projects, the approach of conducting this study as a Multiple Case Study was defined where an interview was made in the form of semi-structured interview (survey) with each responsible for the logistical undertaking in such environments. Yin (2008 apud Miguel, 2010) states that the Case Study is a form of investigation (with empirical nature) that seeks to pursue the preservation of holistic and meaningful characteristics (which cover the situation as a whole in the object of study in question) of events and organizational processes (whether operational administrative or external). The Case Study is, therefore, a search method that enables a qualitative analysis. Richardson (1989 apud Miguel, 2010) states that the analysis of a unit or of a given sample of this universe furthers our understanding of the generality or, at least, the development of structural founda- tions for further analysis, this more comprehensive and better grounded, being able to focus on observation and analysis properties and specific parameters of their relationships and variations on the theme object of study, and through qualitative techniques, draw valid conclusions for the same context.

\section{Results}

\section{CASE I}

The main variables of strategic analysis of the logistical undertaking, which aggregate operational activities performed in the project with the organizational planning of the company, according to research conducted by the authors, can be presented as follows (Table I):

The logistical undertaking serves clients that use the Port of Itajaí to flow and loading of raw materials and products, in addition to attend directly the berths of the port if necessary, because it works as well as an auxiliary structure for transport and storage to offload the cargo port terminal. In the logistics platform in question it was found the presence of warehouses with adequate infrastructure to conduct transshipment cargo operations of picking / packing, cargo consolidation and deconsolidation, distribution and shipping. Among the supply chains met, there are especially those related to heavy-metal industry (vehicles, machinery, motors) and especially those that cater to pharmaceutical network and chemical manipulation, being currently the most representative customers' chain platform. Among its main clients are companies such as Chery Motors, Roche, Siemens, Sebrace, WEG, General Electric, Philips, New Holland, Souza Cruz, Intelbrás, FIAT, among others.

\section{CASE 2}

The main variables of strategic analysis of the logistical undertaking, which aggregate operational activities performed in the project with the organizational planning of the company, according to research conducted by the authors, can be presented as follows (Table 2):

The logistical undertaking serves clients that use the Port of Itajaí to flow and loading reefer containers, working as an auxiliary structure for transport and storage to offload the reefer cargo port terminal (demand is way over the offer according to the manager). They have an excellent infrastructure to conduct transshipment cargo operations since they operate reefer containers only. Among its main clients are companies such as BRF, JBS-Friboi, Perdigão, Macedo.

\section{CASE 3}

The main variables of strategic analysis of the logistical undertaking, which aggregate operational activities performed in the project with the organizational planning of the com- 


\begin{tabular}{|c|c|c|}
\hline Integration & Services Offered & Operating Parameters \\
\hline $\begin{array}{l}\text { IT integrator infrastructure:Yes, } \\
\text { the environment provides an } \\
\text { integrated IT structure between } \\
\text { the agents and the company. } \\
\text { WEB platform (virtual platform, } \\
\text { intranet and extranet) intercon- } \\
\text { nected with the IRS system. }\end{array}$ & $\begin{array}{l}\text { Transport Management: Integra- } \\
\text { tion with carriers (via WEB Plat- } \\
\text { form), own tracking equipment, } \\
\text { use of RFID / NFC; }\end{array}$ & $\begin{array}{l}\text { Lead time (time between the } \\
\text { exit of the goods from the ship- } \\
\text { per 'till its receipt by the cus- } \\
\text { tomer): It's able to handle load- } \\
\text { ing and unloading unscheduled } \\
\text { (emergency) within } 48 \text { hours; }\end{array}$ \\
\hline $\begin{array}{l}\text { Intermodality: There is joint use } \\
\text { of more than one modal and } \\
\text { equipment to assist in opera- } \\
\text { tions; }\end{array}$ & $\begin{array}{l}\text { Storage: warehouses suitable } \\
\text { for the handled loads (cooling, } \\
\text { security, location within the } \\
\text { warehouse, area for materials } \\
\text { with higher added value, among } \\
\text { others); }\end{array}$ & $\begin{array}{l}\text { Reliability (in deadlines, of secu- } \\
\text { rity - theft, damage, loss, etc.).: } \\
\text { Attached to the Receita Feder- } \\
\text { al's handling. Security services } \\
\text { offered in specific cases out- } \\
\text { sourced to standard operations; }\end{array}$ \\
\hline $\begin{array}{l}\text { Accessibility to the consumer } \\
\text { market: Existing and wide, model } \\
\text { capillarity and direct connection } \\
\text { with the BR } 10 \text { I and SC-486; }\end{array}$ & $\begin{array}{l}\text { Processing loads (picking, cross } \\
\text { docking, packaging, consolidation } \\
\text { and deconsolidation, etc):Yes }\end{array}$ & $\begin{array}{l}\text { Logistics costs (transportation } \\
\text { and storage): Included in the ser- } \\
\text { vices offered directly in contract. }\end{array}$ \\
\hline $\begin{array}{l}\text { Accessibility to supply chains: } \\
\text { via Port of Itajaí and adjacent } \\
\text { highways. }\end{array}$ & $\begin{array}{l}\text { Cargo clearance services (cus- } \\
\text { toms, issuing tax documents, } \\
\text { etc):Yes, this is a competitive } \\
\text { advantage in the region. }\end{array}$ & \\
\hline
\end{tabular}

Table I Strategic variables of LP I:

\begin{tabular}{|c|c|c|}
\hline Integration & Services Offered & Operating Parameters \\
\hline $\begin{array}{l}\text { IT integrator infrastructure:Yes, } \\
\text { the environment provides an } \\
\text { integrated IT structure between } \\
\text { the agents and the company. }\end{array}$ & $\begin{array}{l}\text { Transport Management: Low to } \\
\text { none. }\end{array}$ & $\begin{array}{l}\text { Lead time (time between the } \\
\text { exit of the goods from the ship- } \\
\text { per 'till its receipt by the cus- } \\
\text { tomer): best in market for frozen } \\
\text { goods }\end{array}$ \\
\hline $\begin{array}{l}\text { Intermodality: Quick and easy, } \\
\text { works with reefer containers } \\
\text { only. }\end{array}$ & $\begin{array}{l}\text { Storage: warehouses suitable for } \\
\text { the handled loads }\end{array}$ & $\begin{array}{l}\text { Reliability (in deadlines, of secu- } \\
\text { rity - theft, damage, loss, etc.).: } \\
\text { Attached to the Receita Feder- } \\
\text { al's handling. No extra covering }\end{array}$ \\
\hline $\begin{array}{l}\text { Accessibility to the consumer } \\
\text { market: Itajaí Port is the main } \\
\text { port of reefer cargo in Brazil. }\end{array}$ & $\begin{array}{l}\text { Processing loads (picking, cross } \\
\text { docking, packaging, consolidation } \\
\text { and deconsolidation, etc): No. }\end{array}$ & $\begin{array}{l}\text { Logistics costs (transportation } \\
\text { and storage): Included in the ser- } \\
\text { vices offered directly in contract. }\end{array}$ \\
\hline $\begin{array}{l}\text { Accessibility to supply chains: via } \\
\text { BR-I0I }\end{array}$ & $\begin{array}{l}\text { Cargo clearance services (cus- } \\
\text { toms, issuing tax documents, } \\
\text { etc):Yes and unique (unique for } \\
\text { reefer cargo) }\end{array}$ & \\
\hline
\end{tabular}

Table 2 Strategic variables of LP 2:

ISSN: 07I 8-2724. (http://www.jotmi.org) 
pany, according to research conducted by the authors, can be presented in Table 3:

The logistical undertaking serves clients that use the Port of São Francisco do Sul to flow and loading of raw materials (copper and steel) and products (toys, medical supplies, machinery, wine). It's cargo consists in a 90/ I0 split (exports/ imports), and offers a unique service for the heavy-metal industry in the region. In the logistics platform in question it was found the presence of warehouses with adequate infrastructure to conduct transshipment cargo operations of picking / packing, cargo consolidation and deconsolidation, distribution and shipping. It is possible to expand for a brief period of time lifting temporary warehouses to help offloading.Among the supply chains met, there are especially those related to heavy-metal industry (vehicles, machinery, motors) and varieties (wine, toys, tires). Among its main clients are companies from China, USA (main clients), Russia, Germany, Chile, Peru, Bolivia.

\section{Discussion}

Fleury and Fleury (2003) claim that when a correct alignment between the essential competence and competitive strategy, expertise will be maximized. A logistics platform acts as a link in the logistics operations in a supply chain and, for such, its conception is tied to centralized coordination and in collaborative way of logistics operations to which the undertaking proposes and the tenant needs be answered. A logistics platform that seeks to meet the direct needs of their clients based on their region of coverage and whose essence of logistics activities is linked to its ability to allocate and shift their loads sharing spaces, fleet and manpower contemplates a strong integration in logistics activities. It's deeply connected the operational concept of collaboration in the supply chain, in order to minimize costs and better utilization of facilities and assets available.

Collaboration works when partners share space, resources and services, but not its core business or assets. Based upon the work of Mehjerdi (2009) and in conducting the Case Study object in question, three items were detected as drivers of collaboration in the supply chain in a Logistics Platform, influencing them as structural bases for skills that are currently required for logistical undertaking like Logistics Platform, can be visualized in Figure I):

- Integrated supply chain

- $\quad$ Strong corporate governance

- Information technology as operational structure

Many changes have occurred in recent years in the socioeconomic world. With that, profound changes have also occurred within the productive restructure and management

\begin{tabular}{|l|l|l|}
\hline \multicolumn{1}{|c|}{ Integration } & \multicolumn{1}{|c|}{ Services Offered } & \multicolumn{1}{c|}{ Operating Parameters } \\
\hline $\begin{array}{l}\text { IT integrator infrastructure:Yes, } \\
\text { two main IT platforms (ERP for } \\
\text { business, WMS for operations) } \\
\text { controlled by the TOTVS system }\end{array}$ & $\begin{array}{l}\text { Transport Management: Low to } \\
\text { none. }\end{array}$ & $\begin{array}{l}\text { Lead time (time between the } \\
\text { exit of the goods from the ship- } \\
\text { per 'till its receipt by the cus- } \\
\text { tomer): It's able to handle load- } \\
\text { ing and unloading unscheduled } \\
\text { (emergency) within 48 hours; }\end{array}$ \\
\hline $\begin{array}{l}\text { Intermodality:There is joint use } \\
\text { of more than one modal and } \\
\text { equipment to assist in opera- } \\
\text { tions; }\end{array}$ & $\begin{array}{l}\text { Storage: warehouses suitable for } \\
\text { the handled loads, also includes a } \\
\text { sparse area to set up temporary } \\
\text { warehouses when or if needed }\end{array}$ & $\begin{array}{l}\text { Reliability (in deadlines, of secu- } \\
\text { rity - theft, damage, loss, etc.):: } \\
\text { Attached to the Receita Feder- } \\
\text { al's handling. Security services } \\
\text { offered in specific cases out- } \\
\text { sourced to standard operations; }\end{array}$ \\
\hline $\begin{array}{l}\text { Accessibility to the consumer } \\
\text { market: Only through Joinville } \\
\text { and BR-I0I }\end{array}$ & $\begin{array}{l}\text { Processing loads (picking, cross } \\
\text { docking, packaging, consolidation } \\
\text { and deconsolidation, etc):Yes }\end{array}$ & $\begin{array}{l}\text { Logistics costs (transportation } \\
\text { and storage): Included in the ser- } \\
\text { vices offered directly in contract. }\end{array}$ \\
\hline $\begin{array}{l}\text { Accessibility to supply chains: via } \\
\text { BR-I0I (25km distance) }\end{array}$ & $\begin{array}{l}\text { Cargo clearance services (cus- } \\
\text { toms, issuing tax documents, } \\
\text { etc):Yes, this is a competitive } \\
\text { advantage in the region. }\end{array}$ & \\
\hline
\end{tabular}

Table 3 Strategic variables of LP 3:

ISSN: 07I 8-2724. (http://www.jotmi.org)

Journal of Technology Management \& Innovation (c) Universidad Alberto Hurtado, Facultad de Economía y Negocios. 
in order to afford the new scenarios that were drawn. The strategy corresponds, in its organizational context, the ability to work systematically and continuously, adjusting the organization to current and future conditions, with a broad vision of the future and seeking to promote organizational perpetuity. We seeks, through this present study, to analyze these three operational skills in a Logistics Platform in order to understand how its compliance would help such a venture to achieve the main objectives pursued in the design of its strategic planning. The main objectives to be achieved in the strategic planning of the company object of the study are:

a. Greater process agility, providing services with less lead time for their tenants;

b. Optimizing the use of space for input, processing, output and storage of goods;

c. Meet supply chains and adjacent value to the port area with gains for tenants (better services), to the port (the port region reliever) and localized region (fostering bonded warehouse terminals development ;

d. Systems and machinery more modern and better integrated with current systems in place in the organization, promoting greater agility in the process;

Figure 2 graphically represents the main goals of the Strategic Plan of the organization studied, it consistent with the principles and basic definitions of Logistics Platforms and continuously, where a goal enhances the operation of the rear, creating a cyclical and continuous objectification.

These objectives are included in the operational and administrative tasks of the logistical undertaking. By aggregating essential logistical skills for the development of a strategic plan for a logistics enterprise like Logistics Platform, as not-

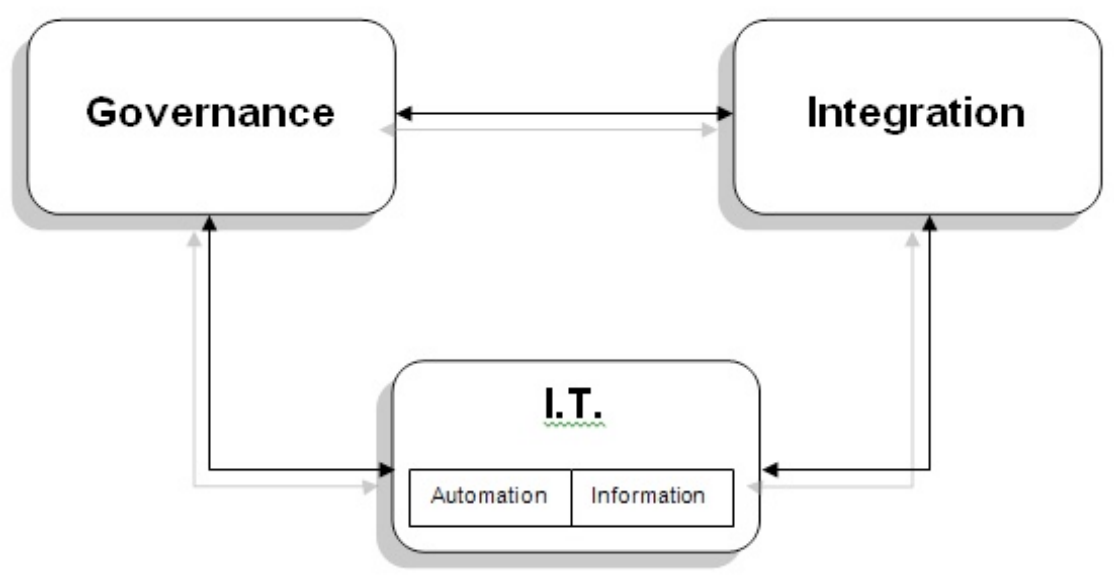

Figure I: Essential Skills in Operation of Logistics Intelligent Platforms.

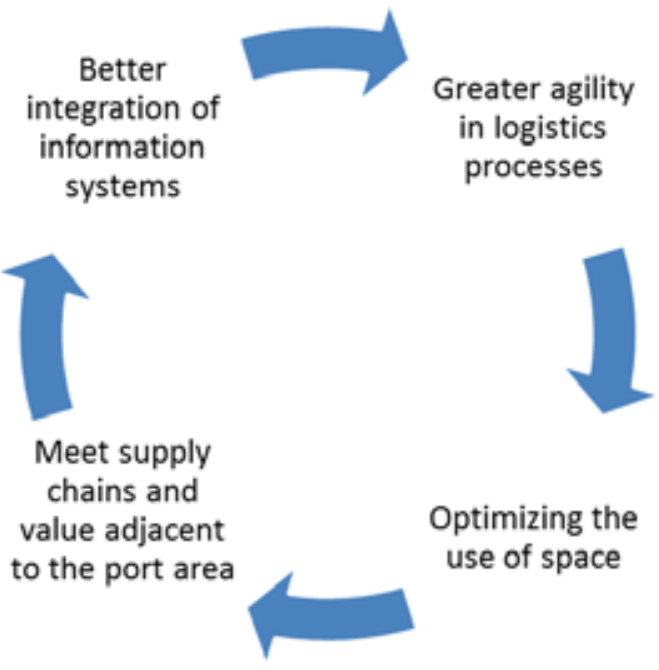

Figure 2: Main objectives in the Strategic Planning Organization.

ISSN: 07 I8-2724. (http://www.jotmi.org) 
ed, the project managers were faced with the question: In what way these three skills raised can influence the goals presented and defined as follows:

\section{Corporate Governance}

Among the managers was full consensus that corporate governance allows to establish ground rules and use of spaces that benefit all links of the value chain involved, assisting in the coordination of logistics activities developed in a Logistics Platform, so this is the competence more linked to the advent of collaborative and sharing of space, technology and control of loads with other organizations involved in the same supply chain and value. Through it, corroborated the managers, you can delegate, clearly and signed duties and rights of tenants and agents, providing guidelines, rules of conduct, safety standards and enforcement, supporting to promote better management of data and requests, providing a basis for a good neighbor policy and logistics control, in addition to being a potential key factor in hiring the services for the stakeholders.

Given its importance in the decisive process of selecting a project in view of those who are clients of the Platform, is possible to affirm and highlight its importance in the organizational strategic planning, it is possible through a good governance, two managers said, attract highly competitive companies in the same market for the same space if there is clarification for organizations that services and logistics processes offered by the project, will add an unique value to their property and clients and offer a mutual competitive advantage, leaving no room for favoritism (or disadvantage) to one of the tenants (something much taken into account, in advent of fear of loss of control over the goods transported) or privilege of a competitor for operations against the other, whether under contract or not. The expansion of the project to accommodate a new logistics park to meet the value chains in the area of Information and Technology supports the previous statement: its construction was possible after research with interested organizations, and for these, one of the priorities was that the new area was to contemplate modern security solutions (loads of high value) and ensured secure access and processing loads for specific customers, using electronic systems and unique accreditation, integrated with the RFID system of the enterprise, ensuring an extra layer of safety.

\section{Integration in the Supply Chain}

Managing the integration of supply chain participants is an arduous task by the number of entities involved and limited by factors such as cultural rivalries, weaknesses and deficiencies in information systems, lack of alignment in manufacturing processes with the strategic plans of the company, among others. It was emphasized by the LP 3 manager in the conduct of this study the importance and relevance that integration between modals of input and output has for the agility of operations within the logistics space, and the existence of specific areas for each type of cargo handled and area of operation of the client. The machinery and aid tools for each type of goods are shared, as well as modal and cradles of the port that serves the region. The integration between the security system and warehouse management system (WMS) diverged. In two cases it is supported by the TMS system (Transportation Management System) and by ERP (Enterprise Resource Planning) and outsourced to the tenants' control through WEB platform (internet to management, intranet for operational monitoring on the spot) and by CRM (Customer Relationship Management). In one case there was a single IT system that was built specifically for the platform, again emphasizing its importance. It was told that the system provided a better management and response time than a generic model for their case, and since it replaced the former efficiency rose. Both cases reinforce the importance that IT plays in this competence and in the strategic planning of the enterprise. This integration contemplates the flows of information and materials: IT organizes and controls the documentation linked to applications, while operational logistics activities, machinery and physical spaces are managed grounded on information disposed by this entity. The integration between flows and before different customers according to Varella et al. (20I2), is a differential of the Platforms: consolidating various processes and agents in the same application, a greater process agility is promoted, allowing a more rational and appropriate use of space for the needs of the answered chains.

\section{Information Technology}

IT serves as an aid instrument and not a tool, a primary source for driving the core business of a Logistics Platform; but helps to make logistics more efficient, is an instrument for value-adding to the chain and enables collaboration and integration inter-organizational within these chains, no matter the location and time (important axes in logistics operations). Currently, according to the managers, the biggest differential in the competitiveness of logistics enterprises like Logistics Platform is grounded in organizations that have a solid IT integrator infrastructure and an avant-garde position, meeting the needs prophylactically, anticipating trends and integrating tools with available systems and assisting tenants in migration and adaptation to that proposed by logistical undertaking.

The adoption of tools without a suitable strategic plan can immobilize the processes and disrupt the overall operation of the enterprise. Given the evolutionary speed of computing and its related technologies, it is recommended the con- 
templation of activities related to IT in long-term strategic planning, requiring regular review and direct contact with customers in order to meet the needs as they arise and not as a prophylactic measure. For Bandeira and Maçada (2008), IT implementation has a high impact on the performance of the supply chain of those involved. Corroborating the statement above, the studies of Feldens (2005) identify six variables impacted by the use of IT in supply chains, which are: Integration, Warehousing Costs, Moving Costs, Speed, Competitiveness and Inter-organizational Coordination. Together, as previously seen in the work of Mehjerdi (2009), there is here also the congruence of two variables directly related to IT that are presented as core competencies in logistics platforms operations: Inter-organizational Coordination and Integration.

The generation of competitive advantage through IT in a logistics environment needs to be agreed between tenants and customers (strengthening the idea of corporate governance as an importance factor), but also proactive, because obsolescence of this type of tool is high and can be the difference between the continuation or termination of a contract on a Platform, said managers. In spite the relevant role of IT in Strategic Planning and in the Supply Chain, to ensure this relevance also in operating activities should not only invest, but provide management measures that seek the integration of IT to logistics, ensuring a better performance in the chains.

\section{Conclusions}

IT is usually the most critical environment on a Logistics Platform, since operations involving cargo handling are activities performed today by no more of the old stockers, but because of the integration between the machinery and the various electronic systems covered by $\mathrm{TI}$ within logistics operations, with systems like EDI (Electronic Data Interchange), WMS (Warehouse Management System), ERP (Enterprise Resource Planning), RFID (Radio-Frequency IDentification), among others. Corroborating the above statement, the findings converged with two variables impacted by the use of IT in supply chains according to Feldens (2005): Integration and Inter-organizational Coordination.Also corroborate the research Mehjerdi (2009) on collaboratively in supply chains, showing the importance of IT in a logistics environment in collaborative work with different supply chains. That is, previous studies show that it is embedded in highly competitive environments, regardless of participation or not of members in the same chain, allowing the same to be isolated in different situations obtaining approximate results. It is therefore, the main tool for managing the flow of information in an organization of services and transportation, and its use in these environments intelligently and integrated with its processes gives support to the two previous skills, providing a secure channel, flexible and of rapid response for the im- plementation of integrated processes, control and management of three major logistics flows (materials, information and financial) and the basis for an enduring strategic planning and focused on other areas of operation beyond the competences above-mentioned.

In designing a strategic plan of a logistics organization of concentration and load management as a Logistics Platform, it can be observed that three competencies, as presented by the authors, emerge as major thrusts of operational activities in order to achieve the main strategic objectives, providing support as for operational characteristics (sizing of the project, design of operating costs, embedded technology) as well as economic (services provided in a logistics environment, value chains to be met, regional aspects intrinsic to operations). These are the integration of the management of supply chains met, clear rules of corporate governance between the parties involved and investments in the area of information technology. Integration can also promote organizational interoperability in a heterogeneous way and independent of other systems, but interconnected with the main interface and collaboratively on the use of physical space and operational equipment in the logistics environment analyzed. Governance is a factor that determines the division of work between companies and improves their activities shaping the capabilities of each participant.

These competences aim at increasing significantly the collaboratively in managing supply chains met. This way, we envisioned that, for better functioning of the supply chain, some activities (except for the core business), in cooperation with other participants in the chain, produces, in fact, positive impacts that strengthen the decisions outlined in its strategic operation plan. These competences strengthen the organizational strategies of these environments, opening up new logistics frontiers and improving the effectiveness of services, besides expand the scope of coverage and add value to your business, serving as a model and enhancing the attractiveness of these projects for current and future tenants.

As analyzed, these can be considered good indicators for an analysis of decision making and operation of a similar logistical undertaking, basing the statements made. They aim to achieve the main goals of a strategic plan for a logistics undertaking similar to a logistics platform. These assumptions, it is possible to say, are cornerstones for the formulation of the strategic plan for an establishment like Logistics Platform, built and linked directly to the location, market strategy and customer's enterprise, properly internalized by agents / clients, where they also seek for their own benefit, enhance the competences, and as Fleury and Fleury (2003) state, with a correct alignment between the core competence and competitive strategy, competence shall be maximized, and its maximization, through instruments for joint 
action involving agents involved, leverage the organization towards its strategic goals and planned objectives.

These competences are therefore directly linked to Information Technology, another competence raised by Varella et al. (20I2). More importantly, IT proved to be a motive competence for the establishment of a logistical undertaking similar to Logistics Platform of modern imprint and facing the efficiency of logistics operations and asset utilization. It is a skill essential to the strategic planning of these logistics projects. But is not dependent solely on the venture, but to the bonds drawn in the constant revision of strategic planning (always changing) organizational, because it also involves joint working between the agents, customers and tenants involved, in a constant improving the tooling and operational, besides the support to the processes involved, available resources and logistical capacity in the region around the project. There for, one can say that IT is the competence of most importance to the organizational strategy of logistics enterprises, because it is the link that supports the other two skills, Integration in the Supply Chain and Corporate Governance.

\section{References}

ABRAHAMSSON, M.; ALDIN, N.; STAHRE, F. (2003) Logistics platforms for improved strategic flexibility. International Journal of Logistics Research and Applications, 6.3, p. 85- 106. ISSN: 1367-5567.

ALBERTINI, A. L. (2004) Administração de Informática: funções e fatores críticos de sucesso Book. 5 ed. São Paulo: Atlas, 2004. ISBN: 9788522452699.

BANDEIRA, R.A. D. M.; MAÇADA,A. C. G. (2008) Tecnologia da informação na gestão da cadeia de suprimentos: o caso da indústria gases. Produção, 18.2, p. 287-30I. ISSN 0103-65I3.

BARBOSA, E. R.; BRONDANI, G. (2004) Planejamento estratégico organizacional. Revista Eletrônica de Contabilidade, I.2, p. I23. ISSN I 98I-0946.

BASTOS, S. Q.A., PEROBELLI, F. S., MACIEL, M.T., SANTOS, T.A. S. dos. (20I0) Plataforma logística: estudo da viabilidade de implantação em Juiz de Fora (MG) via caracterização das mercadorias transportadas entre Minas Gerais e Rio de Janeiro. Revista de Economia, 35. I, ISSN 0556-5782.

BOWERSOX, D. J., CLOSS, D. J., \& STANK, T. P. (2003). How to master cross-enterprise collaboration. Supply Chain Management Review, 7.4, 18-28. ISSN I52I-9747

CARVALHO, C. C. D. (2010) Análise de benchmarking para projeto de plataforma logística: caso da plataforma logística de Campinas. 2010 - Dissertation. FEC-LALT, UNICAMP, Campinas.

COLIN, Jacques. (1996) Les evolutions de la logistique en Europe: vers la polarisation des espaces. I International Seminar: Logistics, Transport and Development. Ceará: UFC/CT/ DET, p. 52-59.

DUARTE, P. C. (1999). Modelo para desenvolvimento de plataforma logística em um terminal: um estudo de caso na estação aduaneira do interior - Itajaí-SC. 1999 - Dissertation. DEPS - UFSC, Florianópolis.

DUBKE, A. F.; FERREIRA, F. R. N.; PIZZOLATO, N. D. (2004) Plataformas Logísticas: características e tendências para $\circ$ Brasil. In: XXIV ENEGEP, Florianópolis.

EUROPLATFORMS. (2004) Logistics Centres Directions for use.Available in <http://j.mp/jYv2Qk>.

FELDENS, L. (2005) Impacto da Tecnologia da Informação nas variáveis estratégicas organizacionais na gestão da cadeia de suprimentos. Porto Alegre. Dissertation. PPGA, UFRGS, Porto Alegre. 
FLEURY, A. C., FLEURY, M. T. L. (2003) Estratégias Competitivas e Competências Essenciais: Perspectivas para a Internacionalização da Indústria no Brasil. Revista Gestão \& Produção, I0.2, p. 129-I44. ISSN: 0104-530x

FLEURY, P. F;;WANKE, P.; FIGUEIREDO, K. F. (2000) Logística empresarial: a perspectiva brasileira. I ed. São Paulo: Atlas. ISBN: 9788522427420

GUNASEKARAN, A.; NGAI, E. (2003) The successful management of a small logistics company. International journal of Physical Distribution \& Logistics Management, 33.9, p. 825842, ISSN 0960-0035.

KOTLER, P. (1992) Administração de marketing: análise, planejamento, implementação e controle. 2. ed. São Paulo: Editora Atlas. ISBN: 97885224 I 825 I

LEE, H. L.;WHANG, S. (2004) E-business and supply chain integration. Book. The Practice of Supply Chain Management: Where Theory and Application Converge. Chapter 6, p. 123I38. ISBN 978-0-387-27275-7.

LIMA, E. T.; CARVALHO JR, M. C.;VELASCO, L. O. M. (1998) Removendo obstáculos às exportações brasileiras. Revista do BNDES.Available in <http://bit.ly/l8ZM7ov>

MEHRJERDI,Y.Z. (2009) The collaborative supply chain. Assembly Automation, 29.2, p. I27-I36. ISSN 0I44-5I 54.

MIGUEL, P. A. C. (2010) Metodologia de pesquisa em engenharia de produção e gestão de operações: Book. Rio de Janeiro: Elsevier. ISBN: 97885352489 I3.

MONTEIRO, A.; BEZERRA, A. L. B. (2003) Vantagem Competitiva em Logística Empresarial Baseada em Tecnologia de Informação. In:VI SemeAd, - FEA/USP, São Paulo.

SAHAY, B. S. (2003) Supply chain collaboration: the key to value creation. Work Study, 52.2, p. 76-83. ISSN: 0043-8022

SIMATUPANG, T. M., WRIGHT, A. C., \& SRIDHARAN, R. (2002) The collaborative supply chain. International Journal of Logistics Management, I 3. I, p. I5-30. ISSN: 0957-4093

STEFANSSON, G. (2005) Collaborative logistics management and the role of third-party service providers. International Journal of Physical Distribution \& Logistics Management 36.2, p. 76-92. ISSN: 0960-0035

VARELLA, L. ; FRAZZON, E. ; NASCIMENTO, H. J. ; GONÇALVES, M. B.; (20II) Proposição de um Modelo Conceitual de Plataforma Logística Adaptado à Realidade do Estado de Santa Catarina. In:XXV ANPET 20I I - Congress of Research and Education in Transportation, Belo Horizonte, Brasil.
VARELLA, L. ; NETO, T. M.; FRAZZON, E. ; GONÇALVES, M. B.; (2012) Competências Essenciais na Operação de Plataformas Logísticas Inteligentes. In: XVII Congreso Panamericano de Ingeniería de Tránsito Transporte $Y$ Logística. PANAM, 20I2, Santiago, Chile.

VIEIRA, C. L. dos S., (20I2) Proposta de um modelo de implantação de tecnologias de informação e comunicação para prestadores de serviços logísticos. Dissertation. DEPS - UFSC, Florianópolis.

VIVALDINI, M.; PIRES, S R I; SOUZA, F B; (20I0) Importância dos Fatores não tecnológicos na implementação do CPFR. Revista de Administração Contemporânea - RAC, 14.2, p. 289-309. ISSN 1982-7849.

WEISBROD, R. E. (2002) Global freight villages:A solution to the urban freight dilemma. In: Proceedings of the 2002 Meeting of the Transportation Research Board, 2002. 